\title{
Further observations on the genetics and morphometrics of Coolia santacroce (Dinophyceae)
}

\author{
Sarah J. Karafas ${ }^{1, *}$ and Carmelo R. Tomas ${ }^{1}$ \\ ${ }^{1}$ Marine Biotechnology Facility, University of North Carolina Wilmington, 5600 Marvin K. Moss Ln., Wilmington, \\ NC 28403, USA
}

Coolia santacroce is a newly described epibenthic dinoflagellate species collected from the U.S. Virgin Islands. The original description indicates this species is unique from others in the Coolia monotis complex due to the relative size of the apical pore complex, broad range of pore sizes, and ribosomal DNA. The original description was done based on the isolation and cultivation of one isolate of the organism. In this study, we report three more isolates of Coolia santacroce collected from the Bahamas. Morphological observations were made using scanning electron microscopy that do not correspond to those from the original description, indicating the variability of the morphological features. However, analysis of the D1 / D2 regions of the large subunit rDNA places the three strains in a strongly supported monophyletic clade with the type specimen.

Key Words: Bahamas; Coolia; cryptic; distribution; genetics; morphology; santacroce

Abbreviations: AP, anteroposterior; APC, apical pore complex; DV, dorsoventral; LSU, large subunit; W, width

\section{INTRODUCTION}

The genus Coolia is comprised of seven species of epibenthic dinoflagellates. The type species C. monotis Meunier (Meunier 1919) was the only Coolia known until 1995 when C. tropicalis Faust (Faust 1995) was described, followed by C. areolata Ten-Hage, Turquet, Quod \& Couté (Ten-Hage et al. 2000), C. canariensis Fraga (Fraga et al. 2008), and C. malayensis Leaw, P. -T. Lim \& Usup (Leaw et al. 2010). Most recently, Karafas et al. (2015) described two new species, C. palmyrensis Karafas, Tomas \& York and C. santacroce Karafas, Tomas \& York, based on morphometric and phylogenetic analyses.

The term Coolia monotis complex was coined to refer to C. monotis, C. malayensis, C. santacroce, and C. palmyrensis (Leaw et al. 2010, Laza-Martínez et al. 2011, Karafas et al. 2015), which are morphologically very similar, despite being phylogenetically distinct. These four species, however, are quite distinct in both genetics and morphology from C. areolata (no genetics available), C. tropicalis and C. canariensis based on the positioning and size of the first apical plate ( $1^{\prime}$ ) (Faust 1995, Ten-Hage et al. 2000, Penna et al. 2005, Dolapsakis et al. 2006, Fraga et al. 2008, Leaw et al. 2010, Laza-Martínez et al. 2011, Jeong et al. 2012, Mohammad-Noor et al. 2013, Momigliano et al. 2013, David et al. 2014, Rhodes et al. 2014, Karafas et al. 2015).

In general, the four species are described as small anteroposteriorly compressed cells with narrow and oblong $1^{\prime}$ plates and a suture between $1^{\prime}$ and 6 " plates that runs
(9) $\$$ This is an Open Access article distributed under the terms of the Creative Commons Attribution Non-Commercial License (http://creativecommons.org/licenses/by-nc/3.0/) which permits unrestricted non-commercial use, distribution, and reproduction in any medium, provided the original work is properly cited.
Received July 19, 2015, Accepted October 3, 2015

*Corresponding Author

E-mail: hutchinsons@uncw.edu

Tel: +1-910-962-3359, Fax: +1-910-962-2410 
straight down the center of the cell (Penna et al. 2005, Dolapsakis et al. 2006, Laza-Martínez et al. 2011, David et al. 2014, Karafas et al. 2015). The four species are genetically distinct according to the internal transcribed spacer and D1 / D2 regions of the ribosomal DNA (Leaw et al. 2010, Karafas et al. 2015). Morphologically C. malayensis, was reported to be similar to C. monotis but smaller in overall size and apical pore complex (APC) dimensions (Leaw et al. 2010), observations that were confirmed by a comparison performed by Karafas et al. (2015). C. palmyrensis is distinguishable from C. malayensis, C. monotis, and C. santacroce by its small cell size, small APC, and sparse number of thecal pores (Momigliano et al. 2013, Karafas et al. 2015). C. santacroce is reported to be closer to C. monotis in size, but retain small APC measurements similar to those of C. malayensis and C. palmyrensis. The type specimen reported from the U.S. Virgin Islands was shown to have two general pore sizes, e.g., large and small, that were distinctly bimodal when plotted (Karafas et al. 2015). However, this species and its features were described from only one strain.

In the present study, we report three additional Coolia isolates that, when analyzed using the D1 / D2 region of the large ribosomal subunit (LSU), phylogenetically identify with C. santacroce, adding validity to the species as described in Karafas et al. (2015). Furthermore, the morphologies of the new isolates were compared with that of the type specimen for the species and implications on the geographic range of the organism are proposed.

\section{MATERIALS AND METHODS}

Three Coolia cells were isolated using single-cell isolation methods from raw water samples that were sent to the Algal Resources Collection (ARC) from the Great Abaco Island in the Bahamas and Nassau, Bahamas (Table 1). Initially single cells were isolated into individual wells of a 96-well plate and then stepped up serially into $250-\mathrm{mL}$ Erlenmeyer flasks that were maintained as living cultures in L1 36 media at $25^{\circ} \mathrm{C}$.

Cells were prepared for scanning electron microscopy as follows: one milliliter of cultured cells was treated with
$4 \%$ Triton and washed with seawater through $5-\mu \mathrm{m} \mathrm{Nu}$ cleopore filters (Whatman, Florham Park, NJ, USA) to remove external membranes. They were then fixed with a $2 \%$ gluteraldehyde solution overnight at $4{ }^{\circ} \mathrm{C}$, rinsed, and dehydrated with two rinses each of 10,30, 50, 75, 95, and $100 \%$ ethanol over a period of two days. The filters containing cells were processed with a critical point dryer, placed on stubs, and coated with $12 \mathrm{~nm}$ of platinum / palladium. Samples were observed on a Philips XLS-FEG scanning electron microscope (Philips, Andover, MS, USA). Measurements of distinctive plate dimensions and pore counts used for morphological comparisons were taken according to Karafas et al. (2015).

The Chelex method was used to extract DNA (Richlen and Barber 2005), and the LSU rDNA D1 / D2 region was amplified using GoTaq Green Mastermix according to the manufacturer's protocol (Promega, Madison, WI, USA). Thermocycler conditions were as follows: initial denaturing at $94^{\circ} \mathrm{C}$ for $2 \mathrm{~min}$ followed by 35 cycles of $94^{\circ} \mathrm{C}$ for 30 s, $50^{\circ} \mathrm{C}$ for $40 \mathrm{~s}, 72^{\circ} \mathrm{C}$ for $1 \mathrm{~min} 45 \mathrm{~s}$ with a final extension period at $72^{\circ} \mathrm{C}$ for $5 \mathrm{~min}$. Amplification products were viewed on a $1 \%$ agarose gel and successful amplicons were cleaned using Exosap-IT (Affymetrix, Santa Clara, CA, USA) and used as templates in Big Dye (v.3.1; Applied Biosystems, Foster City, CA, USA) sequencing reactions. Amplification and sequencing reactions were performed with universal primers D1R and D2C (Scholin et al. 1994). Sequencing reactions were run on an ABI 3100 Genetic Analyzer (DNA Analysis Core Facility, CMS; Applied Biosystems), and edited and assembled using Sequencher (Gene Codes Corp., Ann Arbor, MI, USA). Thirty-eight additional Coolia sequences were imported from Genbank DNA database to be used in D1 / D2 phylogenetic analysis representing six species of Coolia. Muscle alignments for both genes were constructed in MEGA 5.2 (Tamura et al. 2011) using Ostreopsis siamensis and Ostreopsis ovata as outgroups.

The best fit nucleotide substitution model was determined in MEGA to be the Tamura 3-parameter test with gamma correction and used to generate the phylogeny. Maximum likelihood analysis with 1,000 bootstrap replicates was performed using MEGA 5.2. Only support values greater than $50 \%$ were illustrated in the phylogeny.

Table 1. Collection information associated with three strains of Coolia santacroce analyzed in this study

\begin{tabular}{ccccc}
\hline Strain & Genbank accession No. & Location & Latitude & Longitude \\
\hline Cos1503-1 & KT288057 & Nassau, Bahamas & $25^{\circ} 04^{\prime} 45.2^{\prime \prime} \mathrm{N}$ & $77^{\circ} 21^{\prime} 01.2^{\prime \prime} \mathrm{W}$ \\
Cos1503-2 & KT288058 & Nassau, Bahamas & $25^{\circ} 04^{\prime} 45.2^{\prime \prime} \mathrm{N}$ & $77^{\circ} 21^{\prime} 01.2^{\prime \prime} \mathrm{W}$ \\
Cos1503GA & KT288059 & Great Abaco Island & $26^{\circ} 31^{\prime} 33.6^{\prime \prime} \mathrm{N}$ & $76^{\circ} 57^{\prime} 45.0^{\prime \prime} \mathrm{W}$ \\
\hline
\end{tabular}




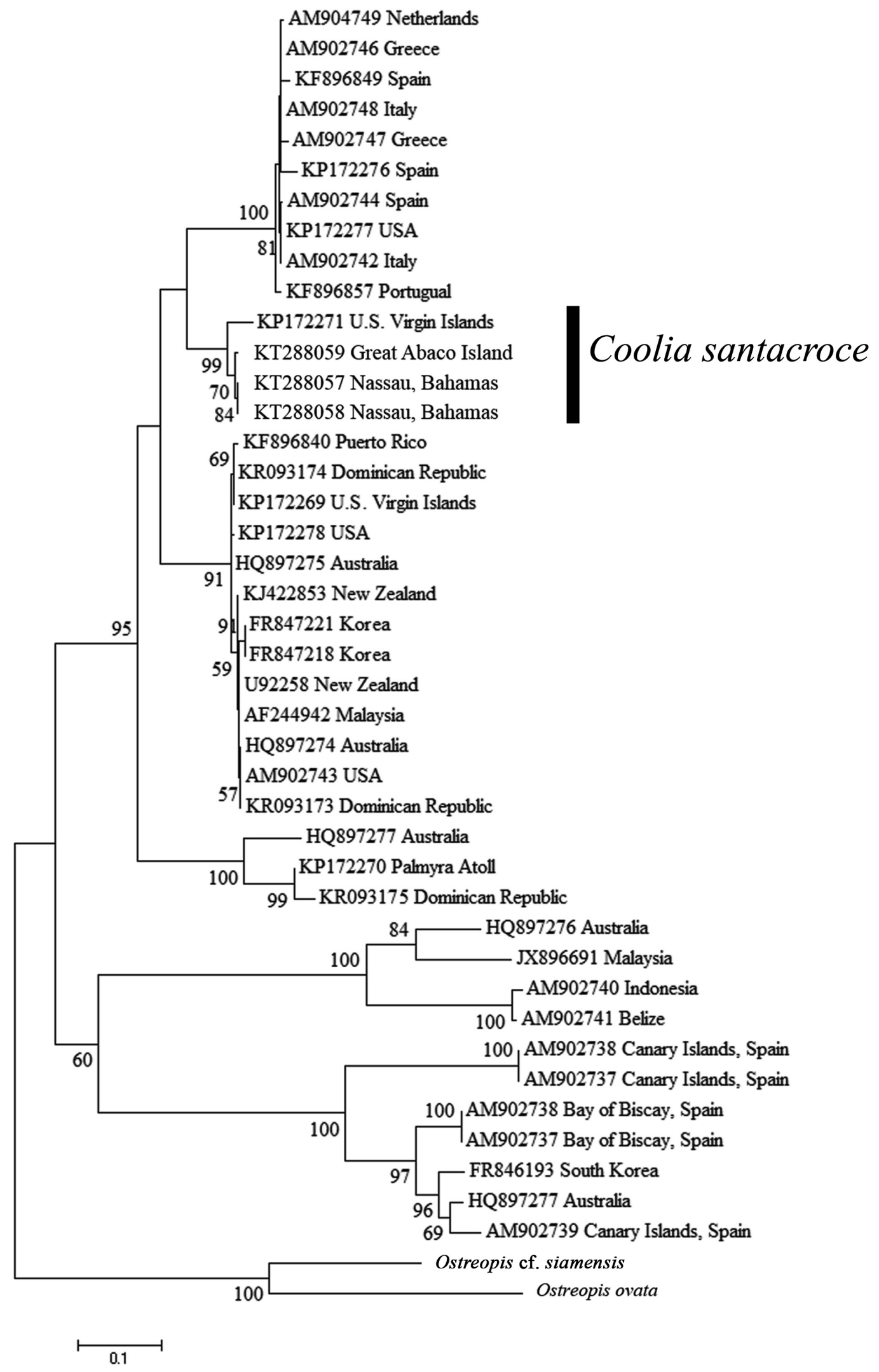

Fig. 1. Maximum likelihood phylogeny of 43 nucleotide sequences using the Tamura 3-parameter model of nucleotide substitution. Bootstrap values above 50 are displayed on clade nodes. Two Ostreopsis species are used as outgroups. 

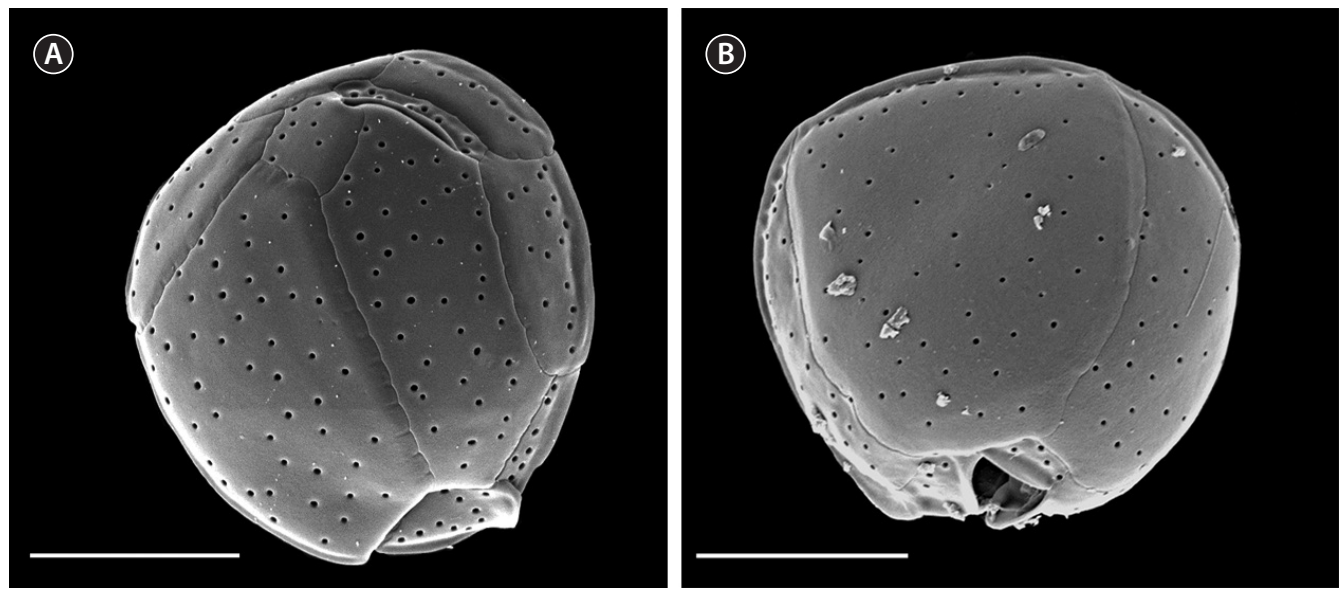

Fig. 2. Scanning electron microscopy images of Coolia santacroce (Cos1503-2) collected from Nassau, Bahamas in epithecal view (A) and hypothecal view (B). Scale bars represent: A \& B, $10 \mu \mathrm{m}$.

\section{RESULTS AND DISCUSSION}

The phylogenetic tree of the D1 / D2 region of the LSU (Fig. 1) resulted in six well supported clades that represent the six currently described Coolia species for which there are genetic data. C. canariensis (including Coolia cf. canariensis) and C. tropicalis were each monophyletic with $100 \%$ support, and were sister taxa to one another with $60 \%$ support. C. monotis, C. malayensis, C. palmyrensis, and C. santacroce grouped together as sister taxa with $95 \%$ bootstrap support in what is referred to as the $C$. monotis complex. Each individual species formed monophyletic clades with support ranging from 91-100\%. The new isolates analyzed in this study were identified genetically as C. santacroce (Cos1503GA, Cos1503-2, and Cos1503-1). Together, with the type specimen for $C$. santacroce published by Karafas et al. (2015), C. santacroce strains formed a monophyletic clade with $99 \%$ bootstrap support.

The relationships shown in this phylogenetic analysis mirrored those found by Karafas et al. (2015), suggesting that $C$. santacroce is more closely related to C. monotis than to C. malayensis. However, while the addition of isolates strengthened the taxonomic identity of C. santacroce as a true species, the bootstrap support values describing the observed relationships are fairly low but may be clarified when more strains are collected and analyzed.

Based on the molecular analysis, only plate measurements that were determined in Karafas et al. (2015) to be distinctive in C. santacroce were measured in this study (dorsoventral, width, anteroposterior, APC, and pore sizes). Preliminary tests showed no significant difference in the measurements between the three new C. santacroce isolates and measurements from all three were pooled. Likewise, one strain was chosen as a representative for all three in Fig. 2. The means of three of the five measurements were smaller than those reported previously for C. santacroce (Karafas et al. 2015) from the U.S. Virgin Islands. Anteroposterior length was $22.6 \pm 2.7 \mu \mathrm{m}(\mathrm{n}=11)$, cell width was $22.7 \pm 2.0 \mu \mathrm{m}(\mathrm{n}=21)$, and dorsoventral depth was $23.9 \pm 2.5 \mu \mathrm{m}(\mathrm{n}=15)$. In general, the overall size of the cells were smaller than C. malayensis as previously reported (Leaw et al. 2010) and corresponded with what was reported previously for C. palmyrensis (Momigliano et al. 2013, Karafas et al. 2015). The APC measurement remained consistent.

Pore sizes remained fairly uniform in the strains examined in the present study $(0.23 \pm 0.06 \mu \mathrm{m}, \mathrm{n}=61)$. Strain Cos1503-1 showed the broadest range of sizes, particularly below the minimum that was previously reported. Very large pores were not observed as they were in the C. santacroce from the U.S. Virgin Islands (Karafas et al. 2015). Pore densities, on the other hand, were as expected, not displaying the sparsity noted in C. palmyrensis. Finally, 1-4 poroids were clearly visible in every pore of every cell observed, contrary to previous reports.

The inclusion of more isolates of C. santacroce served to clarify the phylogenetics of the Coolia genus and strengthen the species' taxonomic status, but did not serve to determine unique morphological characteristics for the species. Characters such as the ratio of APC size to cell size and bimodal pore sizes were presumed to be defining for the species, but are now shown to be subject to more flexible plasticity and geographic variation than 
initially believed. This leaves $C$. santacroce to be referred to as a cryptic species until unique characters not investigated in Karafas et al. (2015) can be identified.

Geographically, the known range for $C$. santacroce now expands further north to include the Bahamas as well as Caribbean islands. While C. santacroce and C. palmyrensis were found to be sympatric with C. malayensis in the U.S. Virgin Islands and Dominican Republic, respectively (Karafas et al. 2015), C. santacroce and C. palmyrensis were not found in the same locations. Regardless, the presently known range of $C$. santacroce and the proximity of the collection locations between C. santacroce and C. palmyrensis strongly suggest that C. malayensis, $C$. palmyrensis, and C. santacroce have ranges that overlap, making identification of Coolia species in this region difficult to determine without microscopic or molecular examination.

\section{CONCLUSION}

Until further evidence emerges, Coolia santacroce appears to be a cryptic species within the Coolia monotis complex. It is genetically distinct but morphologically very similar to Coolia monotis and Coolia malayensis. New clones reveal a wider geographic range of the species than previously known, including the Great Abaco Island and Nassau in the Bahamas.

\section{ACKNOWLEDGEMENTS}

We would like to thank Celia Trefilio and Linus Stoltz for collecting samples from Nassau and the Great Abaco Island, respectively.

\section{REFERENCES}

David, H., Laza-Martínez, A., Miguel, I. \& Orive, E. 2014. Broad distribution of Coolia monotis and restricted distribution of Coolia cf. canariensis (Dinophyceae) on the Atlantic coast of the Iberian Peninsula. Phycologia 53:342-352.

Dolapsakis, N. P., Kilpatrick, M. W., Economou-Amilli, A. \& Tafas, T. 2006. Morphology and rDNA phylogeny of a Mediterranean Coolia monotis (Dinophyceae) strain from Greece. Sci. Mar. 70:67-76.

Faust, M. A. 1995. Observation of sand-dwelling toxic dinoflagellates (Dinophyceae) from widely differing sites, in- cluding two new species. J. Phycol. 31:996-1003.

Fraga, S., Penna, A., Bianconi, I., Paz, B. \& Zapata, M. 2008. Coolia canariensis sp. nov. (Dinophyceae), a new nontoxic epiphytic benthic dinoflagellate from the Canary Islands. J. Phycol. 44:1060-1070.

Jeong, H. J., Yih, W., Kang, N. S., Lee, S. Y., Yoon, E. Y., Yoo, Y. D., Kim, H. S. \& Kim, J. H. 2012. First report of the epiphytic benthic dinoflagellates Coolia canariensis and Coolia malayensis in the waters off Jeju Island, Korea: morphology and rDNA sequences. J. Eukaryot. Microbiol. 59:114133.

Karafas, S., York, R. \& Tomas, C. 2015. Morphological and genetic analysis of the Coolia monotis species complex with the introduction of two new species, Coolia santacroce sp. nov. and Coolia palmyrensis sp. nov. (Dinophyceae). Harmful Algae 46:18-33.

Laza-Martínez, A., Orive, E. \& Miguel, I. 2011. Morphological and genetic characterization of benthic dinoflagellates of the genera Coolia, Ostreopsis, and Prorocentrum from the south-eastern Bay of Biscay. Eur. J. Phycol. 46:45-65.

Leaw, C. -P., Lim, P. -T., Cheng, K. -W., Ng, B. -K. \& Usup, G. 2010. Morphology and molecular characterization of a new species of thecate benthic dinoflagellate, Coolia malayensis sp. nov (Dinophyceae). J. Phycol. 46:162-171.

Meunier, A. 1919. Microplancton de la Mer Flamande. 3. Les Péridiniens. Mem. Mus. R. Hist. Nat. Bruxelles 8:3-116.

Mohammad-Noor, N., Moestrup, Ø., Lundholm, N., Fraga, S., Adam, A., Holmes, M. J. \& Saleh, E. 2013. Autecology and phylogeny of Coolia tropicalis and Coolia malayensis (Dinophyceae), with emphasis on taxonomy of $C$. tropicalis based on light microscopy, scanning electron microscopy and LSU rDNA. J. Phycol. 49:536-545.

Momigliano, P., Sparrow, L., Blair, D. \& Heimann, K. 2013. The diversity of Coolia spp. (Dinophyceae: Ostreopsidaceae) in the Central Great Barrier Reef Region. PLoS ONE 8:e79278.

Penna, A., Vila, M., Fraga, S., Giacobbe, M. G., Andreoni, F., Riobó, P. \& Vernesi, C. 2005. Characterization of Ostreopsis and Coolia (Dinophyceae) isolates in the western Mediterranean Sea based on morphology, toxicity, and internal transcribed spacer 5.8s rDNA sequences. J. Phycol. 41:212-225.

Rhodes, L., Smith, K., Gimenez Papiol, G., Adamson, J., Harwood, T. \& Munday, R. 2014. Epiphytic dinoflagellates in sub-tropical New Zealand, in particular the genus Coolia Meunier. Harmful Algae 34:36-41.

Richlen, M. L. \& Barber, P. H. 2005. A technique for the rapid extraction of microalgal DNA from single live and preserved cells. Mol. Ecol. Notes 5:688-691.

Scholin, C. A., Herzog, M., Sogin, M. \& Anderson, D. M. 1994. 
Identification of group- and strain-specific genetic markers for globally distributed Alexandrium (Dinophyceae). II. Sequence analysis of a fragment of the LSU rRNA gene. J. Phycol. 30:999-1011.

Tamura, K., Peterson, D., Peterson, N., Stecher, G., Nei, M. \& Kumar, S. 2011. MEGA5: Molecular evolutionary genetics analysis using maximum likelihood, evolutionary distance, and maximum parsimony methods. Mol. Biol. Evol. 28:2731-2739.

Ten-Hage, L., Turquet, J., Quod, J. P. \& Couté, A. 2000. Coolia areolata sp. nov (Dinophyceae), a new sand-dwelling dinoflagellate from the southwestern Indian Ocean. Phycologia 39:377-383. 